\title{
Analysis of Density Changes of Selected Brain Receptors After a 14-Day Supply of Chromium(III) and Evaluation of Chromium(III) Affinity to Selected Receptors and Transporters
}

\author{
Anna Piotrowska ${ }^{1}$ (D) Agata Siwek $^{2}$ (D) Małgorzata Wolak ${ }^{2}$ (D) Gabriel Nowak $^{2,3}$ (D)
}

Received: 14 July 2019 / Accepted: 26 September 2019 / Published online: 16 November 2019

(C) The Author(s) 2019

\begin{abstract}
Chromium(III) is one of the most controversial biometals. Although, it is no longer on the list of minerals necessary for the proper functioning of the human body, and its pharmacological effect is still under discussion. One of the purposes of Cr(III) administration is to use it in patients with mood disorders and it is strictly related to its pharmacological, not dietary effect. This is because its high doses are necessary to obtain the results and additionally, no deficiencies in human population have been noted. In this study, the affinity of chromium(III) to selected receptors and transporters in the rat brain was evaluated, and the effect of the 14-day administration of this metal was assessed on the density of selected receptors. All analyses were performed in vitro using radioligand binding assays, and the results indicated lack of affinity to $\beta_{1}$ and $\alpha_{1}$ receptors and serotonin transporter (SERT), furthermore very weak affinity to the 5-HT $\mathrm{HT}_{1 \mathrm{~A}}$ receptor ( $30 \%$ inhibition at $10^{-4}$ and $10^{-5} \mathrm{M}$ ). Analysis of the $\alpha_{1}$ and $\beta_{1}$ adrenergic receptor density indicated lack of any adaptive effects after 14 days of $\mathrm{Cr}(\mathrm{III})$ administration through intraperitoneal injections (doses 6 and $12 \mathrm{mg} / \mathrm{kg}$ ). The antidepressant activity of chromium(III) indicated in clinical trials concerned patients with atypical, seasonal, or dystonic symptoms. This effect, as it seems based on the presented results, does not depend on direct affinity to serotonin receptors and transporter nor is the result of adaptive changes in the adrenoreceptor system.
\end{abstract}

Keywords Chromium $\cdot$ Adaptative changes $\cdot$ Pharmacological effect $\cdot$ Mood disorders $\cdot$ Major depression

\section{Introduction}

Currently, chromium(III) is probably the most controversial biometal, and concepts about its role are still changing. In 2014, it was removed from the list of micronutrients [1]. Since then, the evidence that $\mathrm{Cr}(\mathrm{III})$ is not a micronutrient have multiplied $[2,3]$.

The basic biological properties of $\mathrm{Cr}$ (III) relate to its activities in the metabolism of carbohydrates [4], which, apart from the use in supplementation of patients in various states of impaired glucose utilization, allows using $\mathrm{Cr}$ (III) supplementation

Anna Piotrowska

anna.piotrowska@awf.krakow.pl

1 Department of Biochemistry and Basics of Cosmetology, University of Physical Education, al. Jana Pawła II 78, 31-571 Kraków, Poland

2 Department of Pharmacobiology, Jagiellonian University Medical College, Kraków, Poland

3 Department of Neurobiology, Laboratory of Trace Elements Neurobiology, Institute of Pharmacology PAS, Kraków, Poland in patients with PCOS [5]. Other directions of usage were also indicated in available literature. The possibility of influencing the dynamics of the development of cognitive disorders [6], post-stroke protective action [7], and the possibility of using or strengthening the pharmacotherapy of depression, especially atypical, was investigated [8-12]. The first postulates indicating the possibility of antidepressant effect of $\mathrm{Cr}$ (III) were established in 1994 [8, 9]. As it was shown in studies using behavioral tests (a modified swimming test in rats and mice) [13-15] and animal models of depression [16], this is due in varying degrees to effects on noradrenergic, dopaminergic, serotonin, and GABAergic receptors.

The results of the available research are not consistent. Piotrowska et al. [15], in contrast to the results of Khanam and Pallai [13], indicate the participation of the noradrenergic pathway in the antidepressant action of Cr(III). Studies in the mouse model have shown that this activity is partially dependent on the 5-HT $1 \mathrm{~A}$ and 5- $\mathrm{HT}_{2 \mathrm{~A}}$ receptors [14] and the dopaminergic system [15]. On the other hand, the noradrenergic mechanism was indicated by antagonism of $\mathrm{Cr}$ (III) action caused by combined administration with adrenergic receptor antagonists (propranolol, prazosin, yohimbine) and augmentation of 
reboxetine action [15]. It was also conveyed in studies by Franklin and Odontiadis [17] and Attenburrow et al. [18], where higher serotonin levels and downregulation $5-\mathrm{HT}_{2 \mathrm{~A}}$ serotonin receptors have been shown. The participation of the glutamatergic system (AMPA and NMDA receptors) in the FST test in mice was demonstrated by Piotrowska [14]. Khanam and Pillai [13] suggested the involvement of the $\mathrm{K}^{+}$channel. Prof. Khanam's group also indicates that chromium may have an anxiolytic effect and is the consequence of the activation of the serotonin pathway [19]. In addition, a decrease in the concentration of corticosterone in the blood plasma of animals subjected to chronic unpredictable mild stress was observed [16].

Clinical observations of the antidepressant action of chromium(III) salts concern primarily atypical depression, premenstrual syndrome (PMS) and premenstrual dysphoric disorder (PDD), seasonal affective disorders (SAD), and circadian mood swings $[10,11]$. This profile of activities is interesting, and range of impact is slightly different for most current antidepressants.

The influence of chronic Cr(III) administration on the density of brain receptors has not been indicated so far. Chromium(III) affinity to these structures has not been studied. Therefore, the aim of the study was to determine the affinity of $\mathrm{Cr}$ (III) to selected receptors and transporters in rat brain and to evaluate the effect of chronic administration of this salt on the density of $\beta_{1}$-adrenergic and $\alpha_{1}$-adrenergic receptors.

\section{Materials and Methods}

All procedures were approved by the Local Ethical Committee of the Jagiellonian University Medical College, Kraków (112/2009). The experiments were carried out on adult male Wistar rats (180-250 g). The animals were housed under conditions with constant temperature $\left(20-22^{\circ} \mathrm{C}\right)$, a controlled 12:12 light-dark cycle and free access to standard pellet diet and tap water. Each experimental group consisted of 10 animals.

Imipramine $(15 \mathrm{mg} / \mathrm{kg}$, Sigma-Aldrich, Germany) and chromium(III) trichloride $\left(\mathrm{CrCl}_{3} \times 6 \mathrm{H}_{2} \mathrm{O} ; 6 \mathrm{mg} / \mathrm{kg}\right.$ and $12 \mathrm{mg} / \mathrm{kg}$, Sigma-Aldrich, Germany) were administered ip everyday between 9.00 and 11.00 a.m. for 14 days. All compounds were dissolved in $0.9 \%$ saline. Control group of animals received an ip injection of saline (vehicle). The volume of vehicles or drug solutions for ip administrations was $2 \mathrm{ml} /$ $\mathrm{kg}$. Doses of chromium(III) were expressed per elemental $\mathrm{Cr}$ and selected on the basis of Franklin and Odontiadis research and were recalculated due to the use of other salts [17]. In connection with intraperitoneal administration, the dose estimation did not consider differences in oral absorption of chromium(III) chloride and chromium(III) picolinate.
Twenty-four hours after the last injection, rats were killed by decapitation. The cortex and hippocampus separately were rapidly removed from the brain, placed on dry ice, and then transferred into $\mathrm{a}-80{ }^{\circ} \mathrm{C}$ freezer until use.

\section{Radioligand Binding Assay}

\section{$\beta_{1}$-Adrenergic Receptors: Saturation and Inhibition Experiments}

Rat cerebral cortex was homogenized in 20 volumes of icecold Tris- $\mathrm{HCl}$ buffer, $\mathrm{pH}=7.6$ in $25^{\circ} \mathrm{C}$ using Ultra Turrax T25B homogenizer (IKA) and centrifuged at 20,000g for $20 \mathrm{~min}$. After decantation of the supernatant, the pellet was resuspended in 20 volumes of buffer and centrifuged again in the same conditions.

Samples consisted of $240 \mu \mathrm{l}$ of the tissue suspension (10 mg of wet weight), $30 \mu \mathrm{l}$ of $\left[{ }^{3} \mathrm{H}\right] \mathrm{CGP}-12177$ (4-[3-[(1,1dimethylethyl)amino]2-hydroxypropoxy]-1,3-dihydro- $2 \mathrm{H}$ benzimidazol-2-one hydrochloride, $\beta_{1} / \beta_{2}$ antagonist) in concentrations ranged from 0.03 to $3 \mathrm{nM}$ were used to estimate the density of $\beta_{1}$-adrenergic receptors. The inhibition experiments were performed in the same conditions but the concentration of radioligand was $0.2 \mathrm{nM}$.

To evaluate non-specific and total binding, $1 \mu \mathrm{M}$ propranolol and buffer were used respectively. Samples in duplicate were incubated in $37^{\circ} \mathrm{C}$ for $60 \mathrm{~min}$. The incubation was finished by rapid filtration through Whatman GF/C filters and washed using a 96-well FilterMate Harvester (Perkin Elmer, USA). Radioactivity was measured using MicroBeta TriLux-liquid scintillation counter (Perkin Elmer). The protein concentration was estimated using Bradford reagent.

\section{$a_{1}$-Adrenergic Receptors: Saturation and Inhibition Experiments}

Rat cerebral cortex was prepared according to previous procedure. Incubation mixture consisted of $240 \mu \mathrm{l}$ of the tissue suspension (10 mg of wet weight), $30 \mu \mathrm{l}$ of $0.186-3.5 \mathrm{nM}$ $\left[{ }^{3} \mathrm{H}\right]$ prazosine, and $30 \mu \mathrm{l}$ of buffer or $10 \mu \mathrm{M}$ phentolamine to estimate total and non-specific binding respectively. For inhibition experiment, the concentration of radioligand was $0.2 \mathrm{nM}$.

Samples in duplicate were incubated for $30 \mathrm{~min}$ in $25^{\circ} \mathrm{C}$, filtered rapidly through Whatman GF/B filters, and washed with ice-cold buffer. Radioactivity was measured using MicroBeta scintillation counter (Perkin Elmer).

\section{5-HT1A Serotonergic Receptors: Inhibition Experiments}

Rat hippocampi were homogenized in 20 volumes of ice-cold Tris- $\mathrm{HCl}$ buffer $\left(\mathrm{pH}=7.7\right.$ in $25^{\circ} \mathrm{C}$ ). The homogenate was centrifuged in $10,000 \mathrm{~g}$ for $10 \mathrm{~min}$. Pellet was resuspended, 
incubated in $37{ }^{\circ} \mathrm{C}$ for $10 \mathrm{~min}$, and centrifuged again. Reaction mixture consisted of $30 \mu \mathrm{l}$ of $0.01 \mathrm{mM}$ or $0.1 \mathrm{mM}$ $\mathrm{CrCl}_{3}, 30 \mu \mathrm{l}$ of $1 \mathrm{nM}\left[{ }^{3} \mathrm{H}\right] 8-\mathrm{OH}-\mathrm{DPAT}(( \pm)-8$-hydroxy-2dipropylaminotetralin hydrobromide, selective 5-HT1A agonist), and $240 \mu \mathrm{l}$ of tissue suspension ( $5 \mathrm{mg}$ wet weight $/ \mathrm{ml}$ ) was incubated in $37^{\circ} \mathrm{C}$ for $20 \mathrm{~min}$. Incubation was finished by rapid filtration through Whatman GF/B filters and washing with Tris- $\mathrm{HCl}$ buffer. All assays were performed in duplicate. A total of $10 \mu \mathrm{M}$ serotonin was used to estimate non-specific binding.

\section{Testing the Affinity of Chromium(III) to the Serotonin Transporter (5HT-T)}

Rat cortex was homogenized in 20 volumes of ice-cold Tris$\mathrm{HCl}$ buffer $\mathrm{pH}=7.7$ containing $120 \mathrm{mM} \mathrm{NaCl}$ and $5 \mathrm{mM} \mathrm{KCl}$ and centrifuged in 20,000 $\mathrm{g}$ for $20 \mathrm{~min}$. Pellet was resuspended and centrifuged twice in the same conditions. Reaction mixture consisted of $30 \mu \mathrm{l}$ of 0.1 or $1 \mathrm{mM} \mathrm{CrCl}_{3}$ and $30 \mu \mathrm{l}$ of $1 \mathrm{nM}\left[{ }^{3} \mathrm{H}\right]$ citalopram, and $240 \mu \mathrm{l}$ of tissue suspension was incubated in RT for $1 \mathrm{~h}$. Rapid filtration and washing with buffer were performed through Whatman GF/B filters. All assays were performed in duplicate.

\section{Statistical Analysis}

The results were analyzed in GraphPad Prism 4, submitted as means \pm standard deviations. The type of distribution was tested using the Shapiro-Wilk test; to detect outliers, the Grubbs test was used. Differences between groups, while meeting the requirements for the chosen test, were examined by a one-way analysis of variance using the Dunnet test as the post hoc test. The significance level $\alpha=0.05$ was assumed.

\section{Results}

Analysis of chromium(III) affinity to selected receptors and transporters as a pilot study was performed in two points using high concentrations of the examined biometal $\left(10^{-3}-10^{-5}\right)$. At selected concentrations, $\mathrm{Cr}$ (III) did not bind $\left(\alpha_{1}, \beta_{1}\right)$ or was bound extremely weakly $\left(5-\mathrm{SERT}, 5-\mathrm{HT}_{1 \mathrm{~A}}\right)$. The results are shown in Table 1.

The results of the saturation tests were subjected to oneway analysis of variance, and the presence of statistically significant differences in $\beta$-receptor density in the cortices of the rats subjected to 14 days of treatment $\left(F_{(3,16)}=4723 ; p=\right.$ 0.0152 ). The tissues of imipramine-treated animals showed a reduced density of $\beta$-receptors $(p<0.05)$. Tissues of animals receiving chromium(III) salts in both doses $(6$ and $12 \mathrm{mg} / \mathrm{kg})$ did not differ significantly from control tissues (Figs. 1 and 2).

Alpha $_{1}$ receptor density analysis after 14 days of therapy is shown in Fig. 3. The examined cortex did not show
Table 1 Percentage of inhibition of a labeled ligand from its specific ligand-receptor complex

\begin{tabular}{|c|c|c|c|}
\hline Receptor & Radioligand & Cr concentration $[\mathrm{M}]$ & $\%$ of inhibition \\
\hline \multirow[t]{2}{*}{ SERT } & {$\left[{ }^{3} \mathrm{H}\right]$ citalopram } & $10^{-3}$ & $3 \%$ \\
\hline & & $10^{-4}$ & $0 \%$ \\
\hline \multirow[t]{2}{*}{$5-\mathrm{HT}_{1 \mathrm{~A}}$} & {$\left[{ }^{3} \mathrm{H}\right] 8-\mathrm{OH}-\mathrm{DPAT}$} & $10^{-4}$ & $30 \%$ \\
\hline & & $10^{-5}$ & $30 \%$ \\
\hline \multirow[t]{2}{*}{$\beta_{1}$} & {$\left[{ }^{3} \mathrm{H}\right] \mathrm{CGP}-12177$} & $10^{-3}$ & $0 \%$ \\
\hline & & $10^{-4}$ & $0 \%$ \\
\hline \multirow[t]{2}{*}{$\alpha_{1}$} & {$\left[{ }^{3} \mathrm{H}\right]$ prazosin } & $10^{-3}$ & $0 \%$ \\
\hline & & $10^{-4}$ & $0 \%$ \\
\hline
\end{tabular}

statistically significant differences $\left(F_{(3.16)}=0.03259 p=\right.$ 0.9918). Figure 4 is an example of the result.

\section{Discussion}

Understanding the mechanism of action of the antidepressant drug may indicate the research direction (new, or already tested and partially confirmed) for sources of disease, which, in the case of depression, is still the current topic. The association of a clinical picture that for depression may be inhomogeneous with the neurobiological mechanism of action of an antidepressant may allow the selection of a group of patients who are more likely to react properly to the prescribed drug. Clinical trials with the use of $\mathrm{Cr}(\mathrm{III})$ supplementation were used in patients with seasonal affective disorder, associated with the menstrual cycle, atypical depression, and dysthymia [10-12, 20, 21]. Patients responded favorably to monotherapy [12] and as augmentation of therapy [20].

In this study, the affinity of chromium(III) to selected receptors and transporters was examined, which is used as a screening method for assessing the suitability of new psychiatric treatments and the effect of chronic administration on the

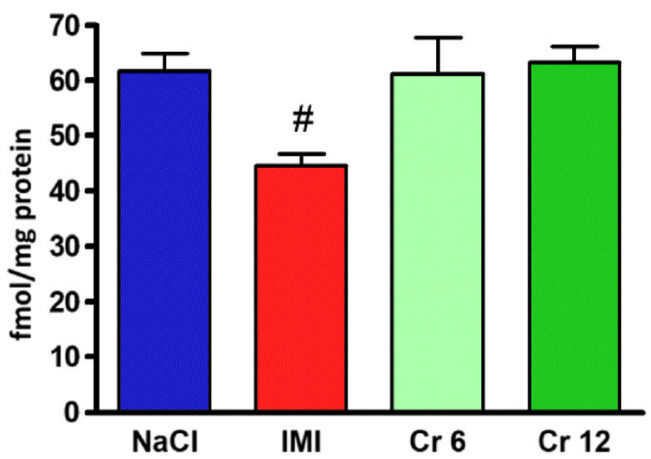

Fig. 1 Beta-adrenergic receptor density in frontal cortex of rats after chronic administration of chromium (Cr 6 in dose $6 \mathrm{mg} / \mathrm{kg}$ or $\mathrm{Cr} 12 \mathrm{in}$ dose $12 \mathrm{mg} / \mathrm{kg}$ ) or imipramine (IMI) expressed as the femtomole per milligram of protein. The result is given as mean $\pm \operatorname{SEM}(n=5)$. $\# p<0.05$ vs. control group $(\mathrm{NaCl})$. Post hoc test: Dunnet 


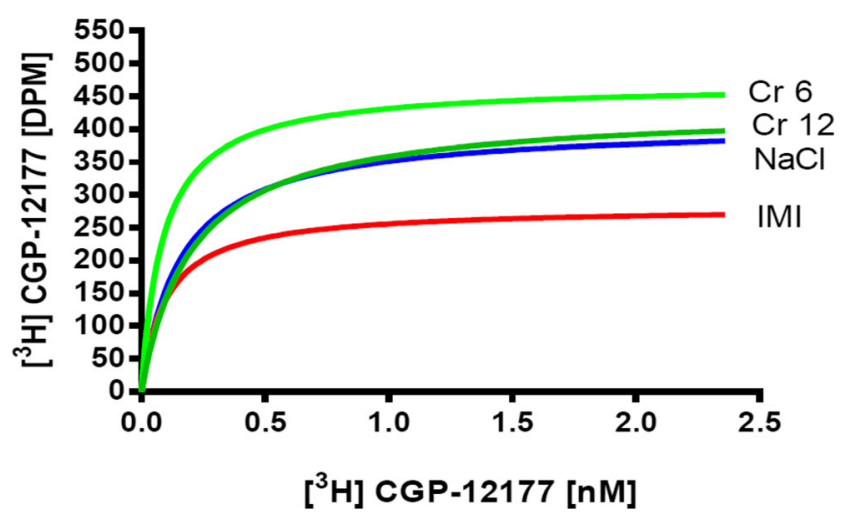

Fig. 2 A representative result of saturation analysis for $\beta$-receptors. IMI imipramine, $\mathrm{NaCl}$ saline, $\mathrm{Cr} 6$ chromium chloride in dose $6 \mathrm{mg} / \mathrm{kg}, \mathrm{Cr} 12$ chromium chloride in dose $12 \mathrm{mg} / \mathrm{kg}$

density of selected receptors in the cortex and hippocampus, and can be considered as an indicator of possible antidepressant effect. In our analyses, we have indicated that $\mathrm{Cr}(\mathrm{III})$ has no affinity to $\alpha_{1}$ and $\beta_{1}$ adrenergic receptors.

Activity to $\alpha_{1}$ and $\beta_{1}$ adrenoreceptors is not an intentional mechanism of action of antidepressants. It can also cause side effects. Lack of direct affinity to the $\alpha_{1}$ receptors may indicate that $\mathrm{Cr}$ (III) will not cause excess sedation, which has never been indicated as an adverse effect when using supplements with this metal $[10-12,20,21]$. On the other hand, blocking the $\alpha_{1}$ adrenoceptor may contribute to development of adaptative changes such as up-regulation, and thus changes desired from a therapeutic point of view.

The role of noradrenaline in the pathophysiology of depression has been repeatedly confirmed [for review: 22]. The individual receptors of the noradrenergic system differ in their function in the aspect of the mechanism of action of antidepressants. Blockade of $\alpha_{1}$ receptors mimics the symptoms of a depressive state (which, like chronic stress, may be associated with desensitization of these receptors) [23]. Some antidepressants show high affinity to the $\alpha_{1}$ receptors (amitriptyline, mianserin) and $\alpha_{2}$ (doxepin, imipramine, mirtazapine, or nortriptyline), which is their characteristic feature after single administration. Completely different effects occur after chronic

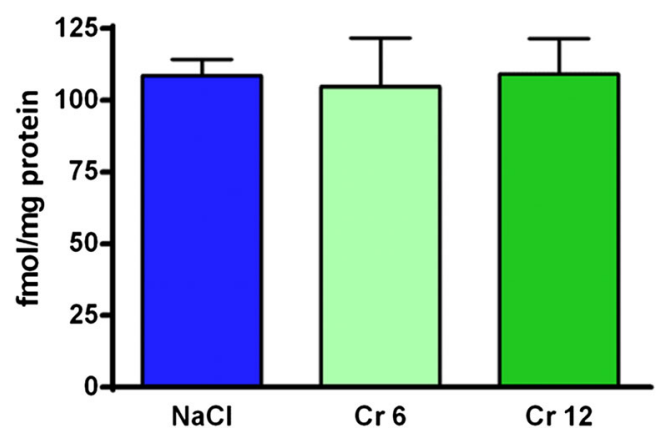

Fig. 3 Density of $\alpha_{1}$-adrenergic receptors in the cortex of rats after chronic administration of chromium ( $\mathrm{Cr} 6$ in dose $6 \mathrm{mg} / \mathrm{kg}$ or Cr 12 in dose $12 \mathrm{mg} / \mathrm{kg}$ ) or saline $(\mathrm{NaCl})$. The result is given as mean $\pm \operatorname{SEM}(n=5)$ administration. Such therapy, like repeated electroconvulsive treatments, increases the density of $\alpha_{1}$ receptors in the frontal cortex and hippocampus [22, 24], while the number of $\alpha_{2}$ receptors decreases $[22,25]$.

Adaptive changes of $\alpha_{1}$ and $\beta_{1}$ receptors have been repeatedly used as one of the markers of antidepressant activity of newly discovered drugs. The first detected adaptive change was $\beta$-downregulation [26]. This effect is also caused by electroconvulsive shock (ECS) and most antidepressants (TCAs, MAOIs) except for SSRI, for which results are mixed [27]. In the noradrenergic system, up-regulation of the $\alpha_{1}$ receptors is also observed. This phenomenon has been confirmed by behavioral and electrophysiological studies and is caused by a variety of antidepressants [28-31] and ECS [24]. Currently used drugs (e.g., SSRI) do not give adaptive changes to adrenergic receptors.

Analysis of the density of selected receptors in the frontal cortex of the rats, after chromium(III) chloride administered at doses of 6 and $12 \mathrm{mg} / \mathrm{kg}$ for 2 weeks, gave negative results. In the examined tissues, there was no reduction in the density of $\beta$-receptors nor was there any increase in the density of $\alpha_{1}$ receptors. It is known that not all drugs with clinically proven antidepressant activity change the density of adrenergic cortical receptors (e.g., SSRIs do not induce $\beta$-downregulation).

Binding to serotonin receptors and serotonin transporter gave rise to several clinically useful groups of antidepressants. Unlike the earlier TLPD, SSRIs acted to raise levels of serotonin without increasing norepinephrine levels. The most drug-effective in this group is escitalopram. Its precursor, citalopram, has the properties of the most selective inhibitor of the serotonin transporter and the use of only one of the enantiomers further improved the selectivity [32].

In animal models, it was found that inhibition of SERT as well as the $5-\mathrm{HT}_{1 \mathrm{~B}}$ receptor increases the serotonin concentration in the prefrontal cortex, while agonists of this receptor

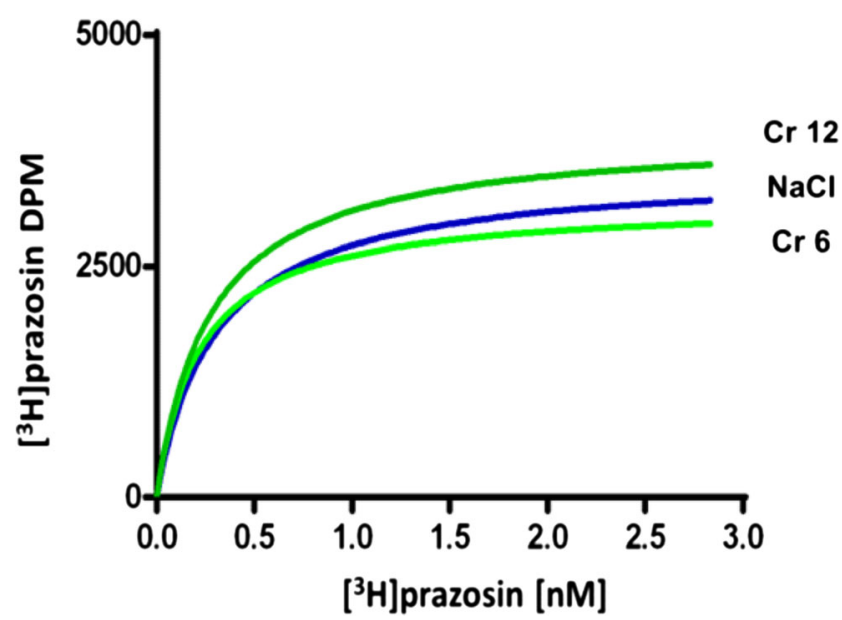

Fig. 4 A representative of the saturation analysis for $\alpha_{1}$-receptor. $\mathrm{NaCl}$ saline, $\mathrm{Cr} 6$ chromium chloride in dose $6 \mathrm{mg} / \mathrm{kg}$, Cr 12 chromium chloride in dose $12 \mathrm{mg} / \mathrm{kg}$ 
increase the rate of firing of serotonergic neurons in the raphe nucleus [33]. This research direction allows new drugs to be introduced into the clinic, e.g., vortioxetine [34]. In presented study on the affinity of $\mathrm{Cr}$ (III) to selected receptors and transporters, no affinity to SERT, $\alpha_{1}$, and $\beta_{1}$ was found; very poor activity was determined in relation to the 5$\mathrm{HT}_{1 \mathrm{~A}}$ receptor.

$5-\mathrm{HT}_{1 \mathrm{~A}}$ are metabotropic receptors coupled to $\mathrm{Gi} / \mathrm{o}$ proteins. Their activation lowers cyclic adenosine monophosphate (cAMP) concentration that leads to the inhibition of neuronal activity. 5-HT releasing is regulated by $5-\mathrm{HT}_{1 \mathrm{~A}}$ autoreceptors by the negative feedback mechanism in nuclei neurons. 5- $\mathrm{HT}_{1 \mathrm{~A}}$ autoreceptors are associated with the pathophysiology of anxiety behavior. SSRI treatment increases 5-HT concentration in synaptic cleft leading to chronic activation of autoreceptors and in consequence to their desensitization. After several weeks, it effects in further alterations in the firing rates of the serotonergic neurons [35]. Mice with low $5-\mathrm{HT}_{1 \mathrm{~A}}$ autoreceptor expression are more sensitive to stress and respond to SSRI treatment faster than mice with higher expression of these receptors [36]. Authors show that raphe 5- $\mathrm{HT}_{1 \mathrm{~A}}$ autoreceptors have negative influence on 5-HT release. In our research, the affinity of $\mathrm{Cr}(\mathrm{III})$ to the $5-\mathrm{HT}_{1 \mathrm{~A}}$ receptors has been indicated, but in the hippocampus, where they act as postsynaptic receptors.

Postsynaptic 5- $\mathrm{HT}_{1 \mathrm{~A}}$ are heteroreceptors located in amygdala, hippocampus, septum, thalamus, and hypothalamus and response to 5-HT released in these regions [37-39]. There are several lines of evidence that $5-\mathrm{HT}_{1 \mathrm{~A}}$ heteroreceptors are involved in the behavioral response to antidepressant treatment. SSRIs are not active in NSF (novelty-suppressed feeding) test in $5-\mathrm{HT}_{1 \mathrm{~A}}$ knockout mice. In wild-type mice, the behavioral effect of antidepressants in NSF test occurs after chronic treatment with 5- $\mathrm{HT}_{1 \mathrm{~A}}$ agonist-8-OH-DPAT. Administration of 8-OHDPAT exerts antidepressant-like influence on adult hippocampal neurogenesis [40].

The studies of Samuels et al. [38] showed that deletion of $5-\mathrm{HT}_{1 \mathrm{~A}}$ receptors from mature dentate gyrus granule cells abolished the behavioral effect of the fluoxetine in mice. The neurogenesis and expression of hippocampal neurotrophic factor (BDNF and VEGF) as a result of SSRI administration were attenuated in mice lacking $5 \mathrm{HT}_{1 \mathrm{~A}}$ receptors. Certain metals appear to affect the expression of BDNF (zinc, magnesium) [41, 42]. Such actions for chromium(III) have not been confirmed yet.

The use of $\mathrm{Cr}(\mathrm{III})$ in the therapy of psychiatric disorders concerns disorders with a complex manifestation. For today, the mechanism of positive effect of supplementation with this metal remains unclear. However, one should exclude direct action on the receptors of the serotonergic and noradrenergic systems and generation of adaptive changes in the latter system.

\section{Conclusions}

Chromium(III) after 14 days of administration did not cause adaptive changes within the $\alpha_{1}$ and $\beta_{1}$ receptors in rat's brain. The ions of this metal have no affinity to the $\alpha_{1}$ and $\beta_{1}$ receptors. The tested biometal has no affinity to the serotonin transporter (SERT) and the affinity of chromium(III) to the $5-\mathrm{HT}_{1 \mathrm{~A}}$ receptors is very low.

\section{Limitations}

In this experiment, intraperitoneal injection was used due to the fact that chromium(III) chloride is absorbed very poorly form the gut. Data on the penetration of this metal through the blood-brain barrier is limited. The main limitation of this work is lack of brain $\mathrm{Cr}(\mathrm{III})$ level estimations.

\section{Compliance with Ethical Standards}

Conflict of Interest The authors declare that they have no conflict of interest.

Open Access This article is distributed under the terms of the Creative Commons Attribution 4.0 International License (http:// creativecommons.org/licenses/by/4.0/), which permits unrestricted use, distribution, and reproduction in any medium, provided you give appropriate credit to the original author(s) and the source, provide a link to the Creative Commons license, and indicate if changes were made.

\section{References}

1. European Food Safety Authority (2014) Scientific opinion on dietary reference values for chromium. EFSA 12:3845. https://doi.org/ 10.2903/sp.efsa.2017.e15121

2. Vincent JB (2017) New evidence against chromium as an essential trace element. J Nutr 147(12):2212-2219. https://doi.org/10.3945/ jn.117.255901

3. Vincent JB, Lukaski HC (2018) Chromium. Adv Nutr 9(4):505506. https://doi.org/10.1093/advances/nmx021

4. Piotrowska A, Pilch W, Tota $Ł$, Nowak G (2018) Biological significance of chromium III for the human organism. Med Pr 69(2):211223. https://doi.org/10.13075/mp.5893.00625 (Polish)

5. Piotrowska A, Pilch W, Czerwińska-Ledwig O, Zuziak R, Siwek A, Wolak M, Nowak G (2019) The possibilities of using chromium salts as an agent supporting treatment of polycystic ovary syndrome. Biol Trace Elem Res:1-7. https://doi.org/10.1007/s12011019-1654-5

6. Krikorian R, Eliassen J, Boespflug E, Nash T, Shidler M (2010) Improved cognitive-cerebral function in older adults with chromium supplementation. Nutr Neurosci 13:116-122. https://doi.org/10. 1179/147683010X12611460764084

7. Chen WY, Mao FC, Liu CH, Kuan YH, Lai NW, Wu CC, Chen CJ (2016) Chromium supplementation improved post-stroke brain infarction and hyperglycemia. Metab Brain Dis 31(2):289-297. https://doi.org/10.1007/s11011-015-9749-y

8. McCarty M (1994) Enhancing central and peripheral insulin activity as a strategy for the treatment of endogenous depression-an adjuvant role for chromium picolinate? Med Hypotheses 43:247252 
9. McCarty M (1994) Longevity effect of chromium picolinate-'rejuvenation' of hypothalamic function? Med Hypotheses 43:253-265

10. Davidson J, Abraham K, Connor K, McLeod M (2003) Effectiveness of chromium in atypical depression: a placebocontrolled trial. Biol Psychiatry 53:261-266

11. Docherty J, Sack D, Roffman M, Finch M, Komorowski J (2005) A double-blind, placebo-controlled, exploratory trial of chromium picolinate in atypical depression: effect on carbohydrate craving. J Psychiatr Pract 11:302-314

12. McLeod MN, Golden RN (2000) Chromium treatment of depression. Int J Neuropsychopharmacol 3(4):311-314. https://doi.org/10. 1017/S146114570000208X

13. Khanam R, Pillai K (2006) Effect of chromium picolinate on modified forced swimming test in diabetic rats: involvement of serotonergic pathways and potassium channels. Basic Clin Pharmacol Toxicol 98: 155-159. https://doi.org/10.1111/j.1742-7843.2006.pto 288.x

14. Piotrowska A, Młyniec K, Siwek A, Dybała M, Opoka W, Poleszak E, Nowak G (2008)Antidepressant-like effect of chromium chloride in the mouse forced swim test: involvement of glutamatergic and serotonergic receptors. Pharmacol Rep 60(6):991-995

15. Piotrowska A, Siwek A, Wolak M, Pochwat B, Szewczyk B, Opoka W, Poleszak E, Nowak G (2013) Involvement of the monoaminergic system in the antidepressant-like activity of chromium chloride in the forced swim test. J Physiol Pharmacol 64(4):493-498

16. Dubey VK, Ansari F, Vohora D, Khanam R (2015) Possible involvement of corticosterone and serotonin in antidepressant and antianxiety effects of chromium picolinate in chronic unpredictable mild stress induced depression and anxiety in rats. J Trace Elem Med Biol 29:222-226. https://doi.org/10.1016/j.jtemb.2014.06.014

17. Franklin M, Odontiadis J (2003) Effects of treatment with chromium picolinate on peripheral amino acid availability and brain monoamine function in the rat. Pharmacopsychiatry. 36:176-180. https:// doi.org/10.1055/s-2003-43046

18. Attenburrow M, Odontiadis J, Murray B, Cowen P, Franklin M (2002) Chromium treatment decreases the sensitivity of 5-HT2A receptors. Psychopharmacology 159:432-436. https://doi.org/10. 1007/s00213-001-0960-7

19. Khanam R, Pillai KK (2007) Effect of chronic chromium picolinate in animal models of anxiety and memory. Fundam Clin Pharmacol 21(5):531-534. https://doi.org/10.1111/j.1472-8206.2007.00503.x

20. McLeod MN, Gaynes BN, Golden RN (1999) Chromium potentiation of antidepressant pharmacotherapy for dysthymic disorder in 5 patients. J Clin Psychiatry 60(4):237-240

21. Brownley KA, Girdler SS, Stout AL, McLeod MN (2013) Chromium supplementation for menstrual cycle-related mood symptoms. J Diet Suppl 10(4):345-356. https://doi.org/10.3109/ 19390211.2013.830678

22. Brunello N, Blier P, Judd L, Mendlewicz J, Nelson C, Souery D, Zohar J, Racagni G (2003) Noradrenaline in mood and anxiety disorders: basic and clinical studies. Int Clin Psychopharmacol 18:191-202. https://doi.org/10.1097/01.yic.0000073880.93678.68

23. Stone E, Grunewald G, Lin Y, Ahsan R, Rosengarten H, Kramer H, Quartermain D (2003) Role of epinephrine stimulation of CNS alpha1-adrenoceptors in motor activity in mice. Synapse. 49:6776. https://doi.org/10.1002/syn.10212

24. Vetulani J, Antkiewicz-Michaluk L, Rokosz-Pelc A, Pilc A (1984) Alpha up-beta down adrenergic regulation: a possible mechanism of action of antidepressant treatments. Pol J Pharmacol Pharm 36:231-248

25. Flügge G, van Kampen M, Meyer H, Fuchs E (2003) Alpha2A and alpha2C-adrenoceptor regulation in the brain: alpha2 $\mathrm{A}$ changes persist after chronic stress. Eur J Neurosci 17(5):917-928

26. Vetulani J, Sulser F (1975) Action of various antidepressant treatments reduces reactivity of noradrenergic cyclic AMP-generating system in limbic forebrain. Nature 257:495-496. https://doi.org/10.1038/257495a0

27. Nalepa I, Vetulani J (1993) Enhancement of responsiveness of cortical adrenergic receptors by chronic administration of the 5- hydroxytryptamine uptake inhibitor citalopram. J Neurochem 60: 2029-2035. https://doi.org/10.1111/j.1471-4159.1993.tb03487.x

28. Maj J (1984) Central effects following repeated treatment with antidepressant drugs. Pol J Pharmacol Pharm 36:87-99

29. Rogóz Z, Wróbel A, Dlaboga D, Dziedzicka-Wasylewska M (2002) Effect of repeated treatment with mirtazapine on the central dopaminergic D2/D3 receptors. Pol J Pharmacol 54:381-389

30. Rogóz Z, Kolasiewicz W (2001) Effect of repeated treatment with reboxetine on the central alpha1-adrenergic system. Pol J Pharmacol 53:663-667

31. Maj J, Rogóz Z, Dlaboga D, Dziedzicka-Wasylewska M (2000) Pharmacological effects of milnacipran, a new antidepressant, given repeatedly on the alpha1-adrenergic and serotonergic 5-HT2A systems. J Neural Transm 107:1345-1359. https://doi.org/10.1007/ s007020070022

32. Sanchez C, Bergqvist PBF, Brennum LT, Gupta S, Hogg A, Larsen A, Wilborg O (2003) Escitalopram, the S-(+)-enantiomer of citalopram, is a selective serotonin reuptake inhibitor with potent effects of animal models predictive of antidepressant and anxiolytic activities. Psychopharmacol. 167:353-362. https://doi.org/10.1007/s00213-002-1364-z

33. Mork A, Pehrson A, Brennum LT, Nielsen SM, Zhong H, Lassen AB et al (2012) Pharmacological effects of Lu AA21004: a novel multimodal compound for the treatment of major depressive disorder. J Pharmacol Exp Ther 340:666-675. https://doi.org/10.1124/ jpet.111.189068

34. Sowa-Kućma M, Pańczyszyn-Trzewik P, Misztak P, Jaeschke RR, Sendek K, Styczeń K, Datka W, Koperny M (2017) Vortioxetine: a review of the pharmacology and clinical profile of the novel antidepressant. Pharmacol Rep 69(4):595-601. https://doi.org/10.1016/ j.pharep.2017.01.030

35. Yohn CN, Gergues MM, Samuels BA (2017) The role of 5-HT receptors in depression. Mol Brain 10(1):28-12. https://doi.org/ 10.1186/s13041-017-0306-y

36. Richardson-Jones JW, Craige CP, Guiard BP, Stephen A, Metzger KL, Kung HF et al (2010)5-HT1A autoreceptor levels determine vulnerability to stress and response to antidepressants. Neuron. 65(1):40-52. https://doi.org/10.1016/j.neuron.2009.12.003

37. Garcia-Garcia AL, Newman-Tancredi A, Leonardo ED (2014) 5HT(1A) [corrected] receptors in mood and anxiety: recent insights into autoreceptor versus heteroreceptor function. Psychopharmacology. 231(4):623-636. https://doi.org/10.1007/s00213-013-3389-x

38. Samuels BA, Anacker C, Hu A, Levinstein MR, Pickenhagen A, Tsetsenis T et al (2015)5-HT1A receptors on mature dentate gyrus granule cells are critical for the antidepressant response. Nat Neurosci 18(11):1606-1616. https://doi.org/10.1038/nn.4116

39. Tanaka KF, Samuels BA, Hen R (2012) Serotonin receptor expression along the dorsal-ventral axis of mouse hippocampus. Philos Trans R Soc Lond Ser B Biol Sci 367(1601):2395-2401. https:// doi.org/10.1098/rstb.2012.0038

40. Santarelli L, Saxe M, Gross C, Surget A, Battaglia F, Dulawa S et al (2003) Requirement of hippocampal neurogenesis for the behavioral effects of antidepressants. Science. 301(5634):805-809. https:// doi.org/10.1126/science.1083328

41. Cichy A, Sowa-Kućma M, Legutko B, Pomierny-Chamioło L, Siwek A, Piotrowska A, Szewczyk B, Poleszak E, Pilc A, Nowak G (2009)Zinc-induced adaptive changes in NMDA/glutamatergic and serotonergic receptors. Pharmacol Rep 61(6):1184-1191

42. Szewczyk B, Poleszak E, Sowa-Kućma M, Siwek M, Dudek D, Ryszewska-Pokraśniewicz B, Radziwoń-Zaleska M, Opoka W, Czekaj J, Pilc A, Nowak G (2008) Antidepressant activity of zinc and magnesium in view of the current hypotheses of antidepressant action. Pharmacol Rep 60:588-589

Publisher's Note Springer Nature remains neutral with regard to jurisdictional claims in published maps and institutional affiliations. 